\title{
Red Foxen
}

\section{Dr. G. J. Buck, Regina}

In July of 1944 I saw a Red Fox running wild just south of Golspie on the north east coast of Scotland. That was the last time until Sunday evening June 22nd. That evening my wife, small daughter and I went for a short drive westward along the Dewdney road, and had turned south about a mile and a half east of Grand Coulee when we saw two yellow-red animals bound eastwards across a bit of newly graded market road. It was difficult to believe that they were foxes. We stopped, for they had run into a fairly large patch of weeds and clover. Hoping to see more of them we got out of the car and could see the animals looking at us from the sweet clover. We moved towards them and in a moment four red foxes ran from cover out across the open field and shallow sloughs where hundreds of ducks are raising their young. The foxes were practically full-grown and were last seen looking at us from the ruins of an abandoned farmstead half a mile way.

\section{The Editors comment}

A few days after receiving this report many of us heard over the air, and read in the press an account of how group of "sportsmen" had "the time of their lives" hunting out, digging down and destroying these foxes. It was a gruesome story. A picture in the press displayed to the public what these vermin look like after they are dead.

\section{Prairie Chicken Friends}

\section{Miss E. K. Jones, Raymore}

This spring a prairie chicken hatched out eight young in a bush close to our house. As her brood got bigger, she would take them for short walks across the grass and into the wheat field.

They became quite tame and we could observe them at will through the door and windows. Now, that they are full grown, we delight in seeing them come up to the front step and into the vegetable garden. The other day they were picking at the lettuce, and running up and down very anconcerned, with one standing guard. They come in the early morning and just about sun-down.

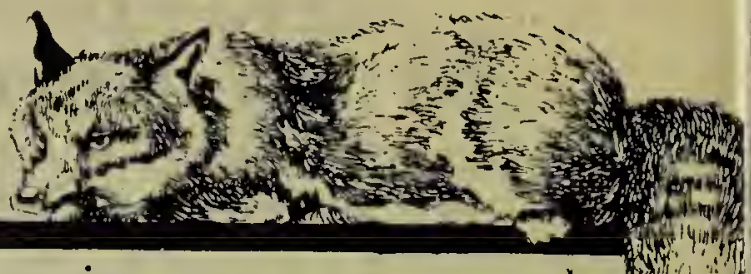

The fox is very scarce on the prairie. Under no stretch of the imagination can it be classified here as a destructive predator. If by any chance a resident should find one in the act destroying his chickens or property, there might be some justification in doing away with it .otherwise there is none.

The fox is one link in the chain of nature; in its own way it helps to maintain the balance which is so essential. The fact that it does destroy a few ducklings may be of concern to the parent duck, but certainly not to "sportsmen", whose only desire is to preserve the ducklings in order that they might shoot them at a later date.

The thoughtless man is the nost destructive predator of all and, wr apped up in his conceit he sometimes believes that he has been granted the Godgiven right of destroying those lower creatures which may interfere with his game bird sport.

Be fore we learned that these foxes were destroyed several different groups had seen them. The thought of killing never entered their minds. They were thrilled at the rare sight; they were pleased that a few of these animals were still around; they admired their beauty, their grace, their cunning; They returned home from their jaunt in the country with a feeling of elation, happy in the thought that they and their children had chanced to drive that way.

\section{A Badger On The Lawn \\ E. K. Jones}

On August 6 , I saw my first badger on the front lawn. It was very tame, and I stood about two feet ways, watching it chew on a bone.

Presently the cat came to see what it was. Her back arched as Mr. B. growled at her like a dog. We both observed the badger for about threequarters of an hour. It just kept on chewing and growling. I had no idea badgers could be so tame. 